\title{
IPTEKS PERATURAN PEMERINTAH NO.71 TAHUN 2010 TENTANG AKUNTANSI PEMERINTAHAN BERBASIS AKRUAL PADA BADAN PENANGGULANGAN BENCANA DAERAH PROVINSI SULAWESI UTARA
}

\author{
Trianti K. A. Pinatik ${ }^{1}$, Leonardo Tumanduk ${ }^{2}$, Novi Swandari Budiarso ${ }^{3}$ \\ 1,2,3 Jurusan Akuntansi, Fakultas Ekonomi dan Bisnis Universitas Sam Ratulangi, Jl. Kampus Bahu, Manado, \\ 95115, Indonesia
}

Email: pinatiktrianti28@gmail.com

\begin{abstract}
Organization of Prov. Regional Disaster Management Agency North Sulawesi Moves in the Field of Disaster Management Operations Centers which need to implement Government Regulation No. 71 of 2010 on accrual bases to provide information from financial records and facilitate more effective performance. In accounting there are two records of the first cash basis and accrual basis. Accrual Basis is the basis for facilitating performance measurement, in regulating clearer and more understandable. This study uses descriptive research methods that aim to explain the circumstances, events or everything related to programs that can be explained in words or numbers. The application of Government Regulation No. 71 of 2010 concerning accrual basis is certainly in accordance with what has been implemented by the Law that has been implemented by the government, Government Accounting Standards, Financial Accounting Standards. Accrual basis application needs financial statements, so that problems can be found or what things are not in accordance with the activities of either budgeting or calculation of budgeting.

Keywords: Accrual Basis, Government Accounting, Government Accounting Standards, Financial Accounting Standards, Descriptive Methods.
\end{abstract}

\section{PENDAHULUAN}

Badan Penanggulangan Bencana Daerah Provinsi Sulut merupakan organisasi yang dibentuk pemerintah untuk memberikan informasi tentang bencana,sesuai amanat yang diberikan pemerintah melalui Undang-Undang nomor 24 tahun 2007. Organisasi ini dibangun karena berlandaskan kondisi geografis dan ekosistem di Provinsi Sulawesi Utara yang menyimpan berbagai permasalahan mengenai bencana yang ada di Provinsi Sulawesi Utara. Menerapkan peraturan pemerintah no.71 tahun 2010 tentang Basis Akrual membantu dalam kinerja organisasi tersebut untuk memberikan informasi yang lebih jelas dalam penggunaan anggaran baik anggaran keluar dan anggaran yang masuk sangat perlu bagi organisasi khusunya pada BPBD Provinsi Sulawesi Utara. Tujuan akuntansi berbasis akrual memberikan informasi yang lebih jelas tentang keuangan mengenai kewajiban keuangan masa yang akan dating pada organisasi Badan Penanggulangan Bencana Daerah Provinsi Sulawesi Utara. Pelaksanaan penerapan basis akrual dapat dilakukan secara bertahap.

\section{TINJAUAN PUSTAKA}

Basis Akrual. Suatu metode untuk mempermudah dan lebih efektif dalam menyusun, mencatat penganggaran yang anggaranya merupakan anggaran untuk masa saat terjadinya bukan biaya dan pendapatan diterima ataupun dibayar adalah Basis Akrual. Basis Akrual adalah dasar dalam mempermudah pengukuran kinerja, dalam mengatur yang lebih jelas dan dapat dipahami.(Kiranayanti,2016). Karakteristik dari basis akrual adalah Bukanlah biaya dan pendapatan yang diterima maupun dibayar dimuka, lebih efektif, bukan hanya itu basis akrual juga dapat mencatat hutang dan piutang. 
Laporan Keuangan. Laporan keuangan berisi tentang informasi dan pencatatan keuangan untuk per periode.(Munawir,2002).

Standar Akuntansi Pemerintahan. Standar Akuntansi Pemerintahan atau yang disingkat SAP merupakan bidang yang ditetapkan pada pemerintahan dan diaplikasikan untuk menyediakan informasi berdasarkan dengan pencatatan keuangan pemerintah.(Bachtiar,2002).

\section{METODE DAN TEKNIK PENERAPAN IPTEKS}

\subsection{Metode Penerapan Ipteks}

Metode ipteks yang diterapkan adalah dengan cara mengimplementasikan apa yang menjadi amanat di pemerintahan

\subsection{Teknik Penerapan Ipteks}

Teknik Penerapan ipteks dilakukan dengan cara bertanya jawab langsung melalui pihak yang bersangkutan.

\section{PEMBAHASAN}

\subsection{Gambaran Objek Penerapan Ipteks}

Lembaga ini sudah berdiri sejak kemerdekaan pada tahun 1945, lembaga pananggulangan bencana ini berkembang dan telah terbagi dalam beberapa peiode pada tahun 1995-1966 dibentuk Badan Penolong Kelurga Korban atau (BPKKP), dan terbentuklag organisasi di daerah-daerah.

\subsection{Pembahasan}

Penerapan Peraturan Pemerintah No.71 Tahun 2010 tentang basis akrual ini tentunya sesuai dengan yang telah diterapkan oleh Undang - Undang yang telah diterapkan oleh pemerintah, Standar Akuntansi Pemerintah, Standar Akuntansi Keuangan. Perlunya diterapkan Peraturan Pemerintah ini karena sangat bermanfaat bagi organisasi, untuk memudahkan dalam penyusunan, penganggaran, pencatatan laporaran keuangan, serta mempermudah bagi organisasi tersebut dalam melakukan kegiatan. Standar Akuntansi Pemerintahan menjelaskan bahwa penerapan ini dapat dilakukan secara bertahap dari Standar Akuntansi Pemerintah berbasis kas sampai menjadi penerapan SAP berbasis akrual. Beberapa hal pokok yang perlu diperhatikan untuk menyusun laporan keuangan adalah entitas akuntansi dan pelaporan yang juga di dukung dalam peraturan pemerintah no. 71 tahun 2010 dengan penjelasan mengelola keuangan, anggaran, kekayaan serta kewajiban yang dimiliki. Penerapan basis akrual perlu adanya Laporan Keuangan, sehingga dapat ditemukannya permasalahan apa atau ada hal apa yang tidak sesuai dengan kegitan baik pencatatan atau perhitungan penganggaran. Perlu diketahui ada beberapa bagian dalam Keuangan Negara Berbasis Akrual. Berikut Merupakan Contoh Dari Laporan Realisasi Keuangan (LRA) Organisasi : Jumlah anggaran dan belanja APBD tahun 2017 Badan Penanggulangan Bencana Daerah Provinsi Sulawesi Utara yaitu sebesar Rp.50.347.243.388,- dengan realisasi keuangan sebesar Rp.47.535.208.413,- atau sebesar 94.41\% dari anggaran yang ditetapkan. Dana APBD yang ada terdiri dari Belanja Tidak Langsung dan Belanja Langsung, dengan perincian sebagai berikut:

Tabel 1. Realisasi Anggaran T.A. 2017

\begin{tabular}{ccrrc}
\hline No. & Uraian & Anggaran (Rp) & \multicolumn{1}{c}{ Realisasi (Rp) } & \% Capaian \\
\hline I & Belanja Tidak Langsung & 6.919 .900 .769 & 6.578 .369 .630 & 95.06 \\
II & Belanja Langsung & 43.427 .342 .619 & 40.956 .838 .783 & 94.31 \\
& T O T A L & $\mathbf{5 0 . 3 4 7 . 2 4 3 . 3 8 8}$ & $\mathbf{4 7 . 5 3 5 . 2 0 8 . 4 1 3}$ & $\mathbf{9 4 . 4 1}$ \\
\hline
\end{tabular}

Sumber : LKIP Badan Penanggulangan Bencana Daerah Provinsi Sulut, 2018. 


\section{KESIMPULAN DAN SARAN}

\subsection{Kesimpulan}

Badan Penanggulangan Bencana Daerah Provinsi Sulawesi Utara, telah melaksanakan Undang - Undang tentang pelaksanaan akuntansi berbasis akrual.

\subsection{Saran}

Perlunya Pengembangan IPTEK untuk mendukung jalan-nya program kerja pada Organisasi BPBD Provinsi Sulawesi Utara.

\section{DAFTAR PUSTAKA}

Arif, Bachtiar dkk. 2002. Akuntansi Pemerintahan Edisi Pertama, Jakarta: Salemba Empat. Baridwan, Z. 1991. Sistem Akuntansi, Edisi Ke-5, Cetakan I, Yogyakarta.

Buku Kita. 2011. Peraturan pemerintah republik indonesia tentang standar akuntansi pemerintahan dan berbasis akrual. Penerbit Visi Media.

Franselki, Kalangi, Runtu. 2015. Analisis Kesiapan Pemerintah Kota Manado Dalam Penerapan Peraturan Pemerintah Nomor 71 Tahun 2010 Mengenai Standar Akuntansi Basis Akrual. 3:1

I . A . I, 2004. Standar Akuntansi Keuangan (SAK). Jakarta: Salemba Empat.

I . A . I, 2015. Pernyataan Standar Akuntansi Keuangan, Yogyakarta.

Kiranayanti. 2016. Pemahaman Basis Akrual, Fakultas Ekonomi dan Bisnis Universitas Udayana, Bali.

Keiso, D. E., Weygandt, J. J dan Warfield, T. D. 2008. Akuntansi Intermediate. Jakarta: Erlangga.

Likip. 2017. Realisasi Anggaran, Badan Penanggulangan Bencana Daerah Provinsi Sulut, Manado.

Likip. 2017. Akuntabilitas Kinerja, Manado.

Munawir. 2002. Analisis Laporan Keuangan, Edisi 4, Yogyakarta Liberty.

Pemerintah Republik Indonesia, 2015. Peraturan Pemerintah Nomor 71 Tahun 2010 tentang Standar Akuntansi Pemerintahan, Medan. 